\title{
Recreating Wakanda by promoting Black excellence in ecology and evolution
}

\author{
Our non-Black colleagues must fight anti-Black racism and white supremacy within the academy to authentically \\ promote Black excellence. Amplifying Black excellence in ecology and evolution is the antidote for white supremacy \\ in the academy.
}

\author{
Christopher J. Schell, Cylita Guy, Delia S. Shelton, Shane C. Campbell-Staton, Briana A. Sealey, \\ Danielle N. Lee and Nyeema C. Harris
}

G rowing protests to decry police brutality and anti-Black racism have demanded sustained efforts for justice in the wake of the murders of Rayshard Brooks, George Floyd, Ahmaud Arbery and Breonna Taylor. Such injustices come at an especially challenging time in which Black communities are disproportionately being ravaged by the global COVID-19 pandemic ${ }^{1,2}$. These compounding issues have culminated in a watershed moment, in which non-Black colleagues, some for the first time, are beginning to legitimately grapple with the pervasive and pernicious nature of anti-Black racism embedded in our institutions and professions.

Many scientific institutions, professional societies and individuals have swiftly and emphatically denounced anti-Black racism, pledging Black Lives Matter and acknowledging their support in deconstructing racial oppression and white supremacy in the academy. This support has largely come in the form of public statements and editorials that elevate Black voices, most notably from prestigious scientific outlets like Nature ${ }^{3,4}$ and Science ${ }^{5-7}$. A recent editorial in Nature Ecology \& Evolution ${ }^{8}$ pledges to dismantle anti-Black racism in the annals of life sciences, which is a necessary step. But let us be clear: this is not enough and not even the minimum ${ }^{9,10}$. The road to anti-racism in academia is a long, arduous, uphill climb that will require institutional and personal reconciliation, resolve, discomfort and humility ${ }^{11}$. It is both necessary and urgent to promote inclusive excellence and transformative scholarship.

Black scholars in the life sciences are grieving, traumatized, exhausted, infuriated, frustrated and experiencing many other disparaging emotions $s^{4,12}$. As we attempt to operate in a system that presents extraordinary barriers to our success, we also watch our white counterparts thrive in a system equipped with the resources made for them ${ }^{7}$. Yet despite the paucity of Black scholars in ecology and evolution ${ }^{13-16}$, repeated evidence emphasizes that scholars from underrepresented groups improve research innovation ${ }^{17}$. The concept of ecosystem integrity emphasizes that species diversity is necessary for ecosystem function, in which rare and keystone species play a disproportionate role in maintaining ecosystem equilibrium ${ }^{18}$. As such, Black scholars are keystone scientists: we play a disproportionate role in advancing diversity and inclusion ${ }^{19}$, while maintaining excellence in teaching and research, despite racial oppression within and outside our academic institutions ${ }^{7}$.

In the Marvel comic series Black Panther, a universe is imagined in which the intellectual, cultural, social and scientific contributions of Black scholars are celebrated. In this fictional nation of Wakanda, the contributions of Black scholars are elevated, emphasizing that global scientific and technological advancements are realized in a world welcoming of Black excellence ${ }^{20}$. To fully realize the beauty and power of Wakanda in our own universe, we must employ anti-racist policies and actions (Fig. 1).

\section{Root mentorship, training and research} in anti-racism

Mentorship, training and research in ecology and evolution must be grounded in institutionalized and formalized anti-racist policies. This means being vulnerable and acknowledging your shortcomings in conversations about racial justice. White supremacy has purposefully suppressed historical narratives of Black contributions to ecology and evolution ${ }^{21}$. This necessarily means that scientists raised in Western society are poorly educated about systemic racial oppression and history by design ${ }^{11}$. Mentors and principal investigators need to be aware of this reality, and must talk to their labs, collaborators and research groups about confronting and dismantling structural racism, especially senior white male colleagues ${ }^{22}$. Importantly, this work extends beyond the white heteronormative male majority, including white women and other minority groups in science.

Be humble enough to relinquish your power and privilege to elevate Black scientists' voices (Fig. 1). Learn to identify microaggressions, guard against them in yourselves, and remain vigilant about eradicating them in your lab group and institutions. Persistence will be required, understanding that fatigue and discomfort will happen. Dig deep.

\section{Decolonize and broaden evaluation metrics}

The guidelines for tenure, promotion and hiring are all heavily steeped in white supremacy and racial oppression that prohibits the full participation and excellence of Black scientists 9 . Tenure, promotion and hiring guidelines customarily devalue community engagement and initiatives directed at promoting diversity, equity, inclusion and justice. This also includes internal and external funding initiatives, as Black life scientists are customarily not funded for large grants ${ }^{23}$. The invisible labour of Black scientists often goes unnoticed or disregarded but is substantial to the excellence of the department and institution ${ }^{24}$.

Radical revisions to evaluation metrics also need to hold non-Black colleagues accountable for anti-racist work. Integration of outreach and engagement efforts should be tantamount to publication record on a CV. Too many non-Black scholars have ascended the academic ladder without substantive contributions to diversifying life sciences and societal justice, and this is unacceptable.

Black scientists (students and faculty included) should serve on tenure and 


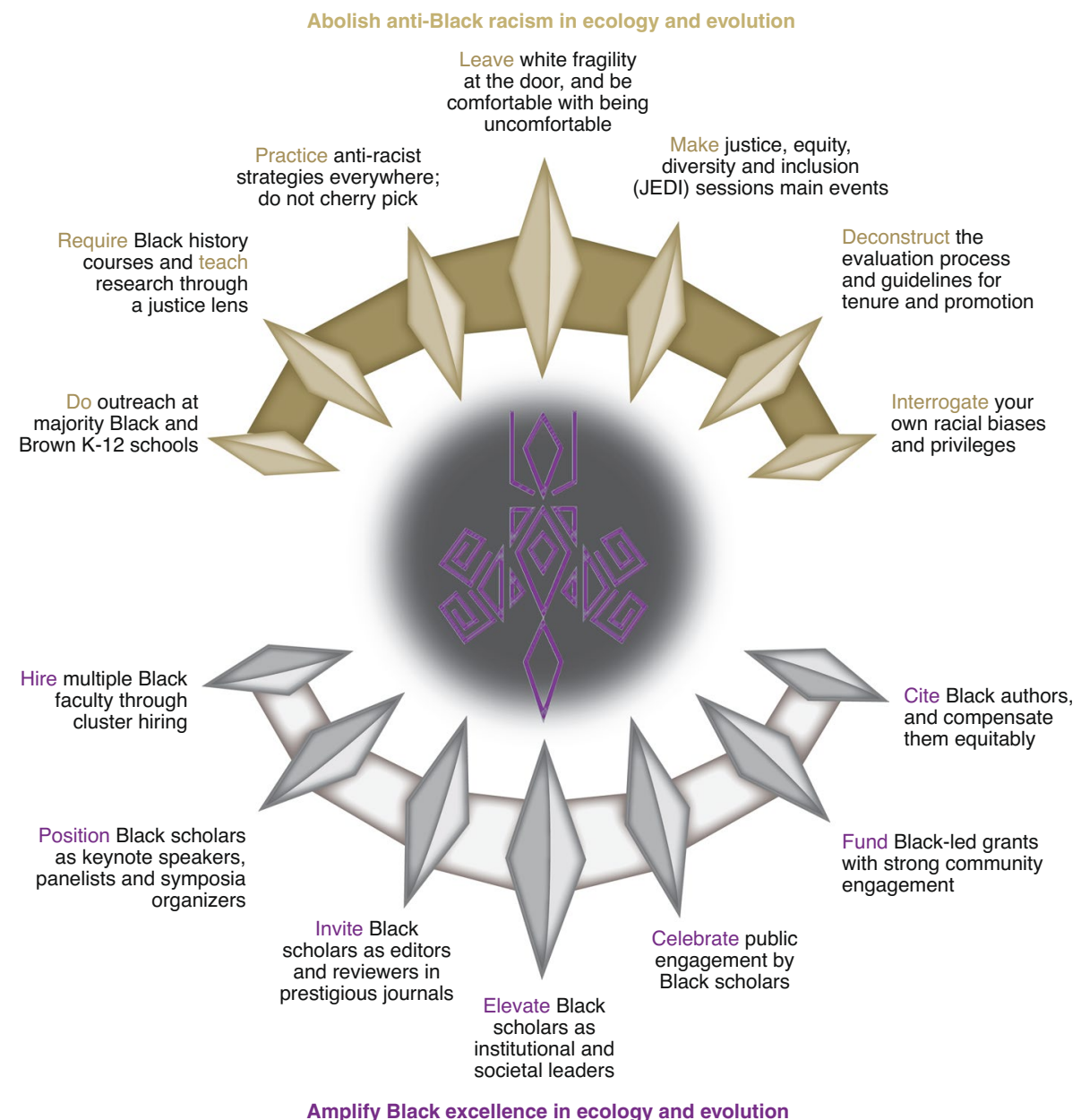

Fig. 1 | Recommendations for authentically amplifying Black scholars while abolishing white supremacy in ecology and evolution. Anti-racist practice and action means creating comprehensive policies that specifically target injustices and inequality at every level of an institution (for example, in lab settings, graduate cohorts, classrooms, conference venues and departmental meetings). Creating sustained change and progress in fighting racial oppression in ecology and evolution requires a multi-tiered approach that incorporates aspects of education, support and personal and professional growth. Most importantly, institutional policies must be married with individual interrogation of biases and privileges, placing accountability at the core of authentically practicing anti-racism pedagogy and doctrine.

promotion committees, as well as hiring committees ${ }^{9}$. The voices and opinions of those Black scholars should seriously be taken into consideration when making all hiring or promotion decisions. Not taking these immediate actions will inevitably jeopardize our ability to create a welcoming environment that broadens participation in our disciplines.

\section{Recognize Black excellence in all its forms}

To authentically be a welcoming space for Black scholars, we need to accept the full expression of Black excellence in all its forms. Concurrently, that means interrogating how societal norms and stereotypes coerce Black scientists to conform or assimilate to a strict definition of professionalism ${ }^{6}$. We do not accept species uniformity in promoting healthy ecosystems, so why would we expect assimilation of personalities, values and cultures? Recent social media movements, including but not limited to \#BlackBirdersWeek, \#BlackintheIvory and \#BlackinNature, illustrate the myriad forms of Black scholarship, education and outreach $^{5}$. Undervaluing these stories, narratives and identities negates the positive contributions our non-Black colleagues make in fighting structural racism.

Support and fight alongside your Black colleagues against racial oppression, especially when it is inconvenient and outside our academic walls. This is especially pertinent for field biologists, as our right to belong in nature without fear of persecution or violence is under constant threat ${ }^{25,26}$. The compounding and pervasive impacts of environmental racism in conservation and environmental movements all contribute to marginalizing Black scholars' contributions to field ecology and biology $y^{16,25,26}$. Authentically recognizing Black excellence will likely mean confronting authority figures (that is, police, deans, chancellors, society presidents, department chairs and so on) and using your privilege to protect the rights of your colleagues.

\section{Sustained work is required}

The best antidote for white supremacy is Black excellence ${ }^{10}$. As James Baldwin famously wrote: "The future of the Negro in this country... Is precisely as bright or dark as the future of the country". Simply put: our collective success in ecology and evolution rests with our willingness to combat anti-Black racism and white supremacy. Our success is also predicated on our ability 
to acknowledge and learn from the historical contributions of acclaimed Black scholars before us. Extensive and untold legacies and narratives of Black scholars in ecology and evolution must be heard ${ }^{16,21}$.

We demand long-term solutions that disrupt white supremacy in all areas of ecology and evolution, while simultaneously elevating Black scholars (Fig. 1). Our current declaration builds on an already exhaustive list of scholarly work addressing anti-racist strategies ${ }^{11}$. May our call to action serve as a preface to lifelong engagement with eradicating systemic racism in our institutions.

Christopher J. Schell (D) $1 \bowtie$,

Cylita Guy (iD)2, Delia S. Shelton (iD)3, Shane C. Campbell-Staton (iD) 4,5, Briana A. Sealey (D), Danielle N. Lee ${ }^{7}$ and Nyeema C. Harris (D)8

${ }^{1}$ School of Interdisciplinary Arts and Sciences, University of Washington Tacoma, Tacoma, WA, USA. ${ }^{2}$ Department of Ecology and Evolutionary Biology, University of Toronto, Toronto, Ontario, Canada. ${ }^{3}$ Environmental and Molecular Toxicology, Oregon State University, Corvallis, OR, USA.
${ }^{4}$ Department of Ecology and Evolutionary Biology, University of California, Los Angeles, CA,

USA. ${ }^{5}$ Institute for Society and Genetics, University of California, Los Angeles, CA, USA. ${ }^{6}$ Department of Integrative Biology, University of Texas at Austin, Austin, TX, USA. ${ }^{7}$ Department of Biological Sciences, Southern Illinois University Edwardsville, Edwardsville, IL, USA. ${ }^{8}$ Applied Wildlife Ecology Lab, Ecology and Evolutionary Biology, University of Michigan, Ann Arbor, MI, USA.

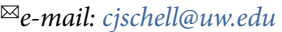

Published online: 24 July 2020

https://doi.org/10.1038/s41559-020-1266-7

References

1. van Dorn, A., Cooney, R. E. \& Sabin, M. L. Lancet 395, 1243-1244 (2020).

2. Yancy, C. W. J. Am. Med. Assoc. 323, 1891-1892 (2020)

3. Nature 582, 147 (2020).

4. Subbaraman, N. Nature 582, 155-156 (2020).

5. Langin, K. 'I can't even enjoy this.' \#BlackBirdersWeek organize shares her struggles as a black scientist. Science (5 June 2020).

6. Spikes, M. Science 368, 1506 (2020).

7. Lewis Jr, N. A. What I've learned about being a Black scientist. Science (16 June 2020); https://doi.org/10.1126/science.caredit. abd 3589

8. Nat. Ecol. Evol. 4, 893-894 (2020)

9. Roberts, J. White academia: do better. Medium (8 June 2020); https://go.nature.com/3fkqpnH
10. Gewin, V. Nature 583, 319-322 (2020).

11. Kendi, I. X. How to Be an Antiracist (One World, 2019).

12. Dzirasa, K. Cell https://doi.org/10.1016/j.cell.2020.06.028 (2020).

13. Tabuchi, H. \& Schlossberg, T. As scientists, we have yet to close the racial disparities. The New York Times (10 June 2020) https://go.nature.com/2DDdteI

14. Leslie, S. J., Cimpian, A., Meyer, M. \& Freeland, E. Science 347 262-265 (2015)

15. Harris, A. The disciplines where no Black people earn PhDs. The Atlantic (19 April 2019); https://go.nature.com/32jTID0

16. Abrahams, R. S. The brief history of African Americans in evolutionary biology, and why that is the case. The Molecular Ecologist (17 February 2020); https://go.nature.com/3eqlihE

17. Hofstra, B. et al. Proc. Natl Acad. Sci. USA 117, 9284-9291 (2020).

18. Garibaldi, A. \& Turner, N. Ecol. Soc. 9, 1 (2004).

19. Jimenez, M. F. et al. Nat. Ecol. Evol. 3, 1030-1033 (2019).

20. Johnson, C. 'Black Panther' and its science role models inspire more than just movie awards. The Conversation (21 February 2019); https://go.nature.com/2Okaaer

1. Lee, D. N. Anim. Behav. 164, 273-280 (2020).

22. Mehta, D. Nature 559, 153 (2018).

23. Hoppe, T. A. et al. Sci. Adv. 5, eaaw7238 (2019).

4. Matthew, P. A. What Is faculty diversity worth to a university? The Atlantic (23 November 2016); https://go.nature.com/2BY37pr

25. Gatheru, W. It's Time for environmental studies to own up to erasing Black people. Vice News (11 June 2020); https://go.nature. com $/ 2 \mathrm{OxMmEd}$

26. Finney, C. Black Faces, White Spaces: Reimagining the Relationship of African Americans to the Great Outdoors (Univ. North Carolina Press, 2014).

Competing interests

The authors declare no competing interests. 